\title{
Influence of Competence and Compensation on the Performance of Employees of Bandung Saung Kabayan Restaurant
}

\author{
Rani Aprilyani ${ }^{1}$, Bagja Waluya ${ }^{1}$, Oce Ridwanudin ${ }^{2}$ \\ ${ }^{1}$ Indonesia University of Education, Jl. Dr. Setiabudhi No. 229, Bandung 40154, Indonesia \\ ${ }^{2}$ NHI Tourism Academy, Jl. Raya Lembang KM 12.8, Kabupaten Bandung Barat 40391, \\ Indonesia
}

*Corresponding Author. E-mail: raniaprilyani@student.upi.edu (Rani Aprilyani),

\begin{tabular}{|l}
\hline ABSTRACT \\
Employee performance from the most vulnerable literature occurs in the restaurant Saung \\
Kabayan Bandung. As low as employees' knowledge and initiative can affect performance. \\
Therefore, improving performance needs to pay attention to competency and compensation \\
factors. This study aims to determine the effect of 1) Competence on employee performance; 2) \\
Compensation for employee performance, and 3) Competence and compensation for employee \\
performance. The dimensions of competency variables (X1) consistency of motives, traits, \\
self-concept, knowledge and skills and; compensation variable (X2) consisting of salary and \\
wages, incentives, benefits, and adequate facilities and; Employee performance variable (Y) \\
consists of work quality, timeliness, initiative, ability, and communication. This research uses a \\
descriptive and verification approach. The method used is an explanatory survey with a sample of \\
56 respondents (saturated sample). The data analysis technique used is multiple linear regression. \\
The results showed that competence and compensation had a positive and significant effect both \\
partially and simultaneously on employee performance at Saung Kabayan Restaurant Bandung \\
with a coefficient value of 67.5\%. Based on research results, competencies need to be improved \\
through training activities, but competencies need to be balanced with fair compensation so as to \\
improve employee performance. \\
Keywords: Competency; Compensation; Employee Performance; Restaurant \\
\hline First Received: April 2019 Revised: Juni 2019 Accepted: September 2019 \\
Final Proof Received: December 2019 \\
\hline \hline Published: December 2019
\end{tabular}




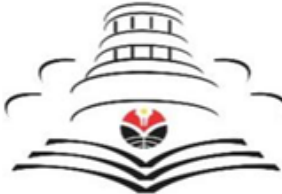

JURNAL UPI
THE JOURNAL GASTRONOMY TOURISM

Volume 6 Issue 2, December 2019, 95-110

Tersedia daring di:

https://ejournal.upi.edu/index.php/gastur

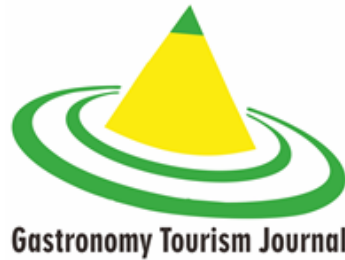

and foreign exchange resources. The tourism industry is defined as a set of related businesses in producing goods and services to meet the needs of tourists on their tourist trips (Ismayanti, 2010). The tourism facility business is in the form of transportation, accommodation, eating and drinking facilities, tirta tourism business and tourism area, including all the facilities or completeness of the tourist destination area needed to serve the needs of tourists.

Indonesia is a country that utilizes tourism as a tourist attraction. A variety of natural beauty and diverse cultural tribes make Indonesia a country worth visiting by foreign tourists.

Bandung City has various types of tourism, namely: nature tourism, shopping tourism and culinary tourism. Culinary tourism is a type of tourism that is experiencing rapid growth. In addition to being a tourist destination, culinary tourism is supporting the needs of tourists to eat and drink during their trips. So, do not be surprised if the culinary industry is increasingly growing. The following is the culinary industry data in Bandung which has been licensed and registered with the Culture and Tourism Office (DISBUDPAR).

Table 1. Data of Restaurants, Restaurants, Cafes and Bars that are licensed in Bandung City Period 2014 - 2017

\begin{tabular}{l|cccc}
\hline \multicolumn{1}{c}{ Year } & 2014 & 2015 & 2016 & 2017 \\
\hline Restaurant & 362 & 378 & 384 & 396 \\
Restaurant & 287 & 305 & 334 & 372 \\
Café & 10 & 12 & 14 & 14 \\
Bar & 8 & 10 & 13 & 13 \\
Amount & 667 & 705 & 745 & 795 \\
\hline \multicolumn{4}{l}{ Source: Bandung City Culture and Tourism Office (2017) }
\end{tabular}

Based on Table 1, it can be seen that growth occurs in all types of culinary industries. A significant increase occurred menus typical of the region.

According to Wurianto in Turgarini (2016) traditional cuisine is a cultural wealth that should be explored as a cultural asset. Therefore, the growth of restaurants in Bandung City is a good impact for the preservation of Sundanese cuisine. But the more the number of restaurants grows, the higher the level of competition between existing restaurants.

Human resources are resources that play an active role in the course of a company and the decision making process. Human resources or known as employees are the only resources that have the feeling, desire, skills, knowledge, encouragement, power and work. All of these potentials have an effect on the company's efforts to achieve its goals (Sutrisno, 2009).

RM Saung Kabayan is one of the culinary industries in Bandung City that has been established since 1988. RM Saung Kabayan is included in the type of special restaurant because this restaurant provides traditional Sundanese cuisine. The tagline owned by RM Saung Kabayan is "Taste of Our Image" which means the taste of the products they serve is a characteristic or image of Saung Kabayan restaurant.

In anticipating existing competition, companies must maximize the capabilities of employees. At present there are 56 employees working at RM Saung Kabayan consisting of several departments. From the number of existing employees, knowledge and initiative have a low value in evaluating employee performance. Knowledge can be increased by taking into account competency factors, while initiatives can be increased by paying attention to compensation factors.

Competence is an ability to carry out or do work or tasks based on skills and 


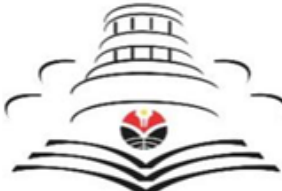

JURNAL UPI
THE JOURNAL GASTRONOMY TOURISM

Volume 6 Issue 2, December 2019, 95-110

Tersedia daring di:

https://ejournal.upi.edu/index.php/gastur

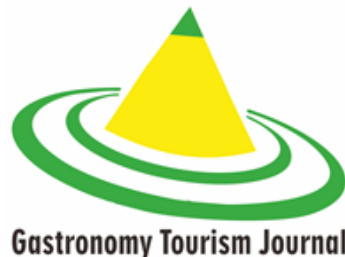

MIr Ed1 as the manager sald that competence will have an impact on employee performance, especially in departments that deal directly with consumers, namely the service / waiter department. Good service can create a sense of comfort for consumers so that consumers feel satisfied after visiting Saung Kabayan restaurant. Conversely, if the services provided are poor, it is unlikely that consumers will visit again. Therefore, to support good service quality competent employees are needed who can maximize their performance.

Competence has a strong relationship with employee performance. This statement is in line with research (Kusumah, 2017) stating that there is a significant influence between competency and employee performance. According to Wibowo (2007), competence is a behavioral dimension that is behind competent performance. Compensation is compensation in the form of financial and tangible services and benefits received by employees in exchange for their contribution to the organization (Simamora, 2004). Following are the compensation provided by Saung Kabayan Bandung Restaurant to Employees :

Table 2. Compensasion Given to Employees

\begin{tabular}{l|c}
\hline Direct Compensation & Indirect Compensation \\
\hline Employee's Salary \pm & Health Benefits \\
Rp 800,000 & \\
Service Incentives & Employments Benefits \\
Are Based On & \\
Turnover/Month & \\
Position allowance of & \\
Rp. 200,000 - Rp. & \\
$1,500,000$ & \\
Holiday allowance & \\
The total is still & \\
below the Bandung & \\
City UMR & \\
\hline
\end{tabular}

compensation according to the company's ability. However, as a solution the company seeks to provide bonuses from the turnover service on a regular basis every month, as well as providing some benefits to employees.

In addition, RM Saung Kabayan determines compensation based on performance appraisals by managers and HRD. Performance appraisal can affect the size of the amount of compensation given, but conversely compensation can also affect one's motivation at work. Therefore, the compensation given must be managed as well as possible so as not to cause complaints, dissatisfaction, or even the resignation of employees from the company.

Seeing the importance of competency and compensation factors on employee performance seen from a research journal conducted by Tahir (2014) states that competence and compensation have an influence on employee performance because competence has implications that determine employee performance improvement but competency alone is not enough without accompanied by managing compensation good, it means that simultaneous and partial implementation of competence and compensation is very important so that employee performance can be optimally improved.

Based on the descriptions above, the authors are interested in further researching how the influence of competence and compensation on improving employee performance.

The formulations of the problem in this study are as follows:

a. How does competence influence employee performance at RM Saung Kabayan? 


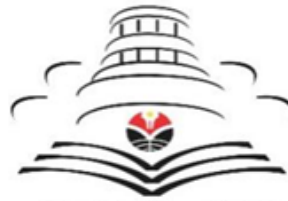

JURNAL UPI
THE JOURNAL GASTRONOMY TOURISM

Volume 6 Issue 2, December 2019, 95-110

Tersedia daring di:

https://ejournal.upi.edu/index.php/gastur

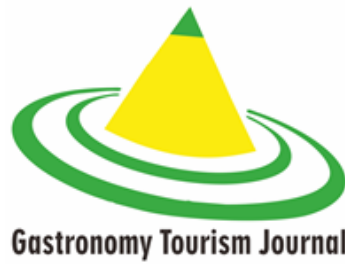

Based on the above problem formulation, the objectives of this study are as follows:

a. To obtain findings regarding the effect of competence on employee performance at RM Saung Kabayan.

b. To obtain findings regarding the effect of compensation on employee performance at RM Saung Kabayan.

c. To obtain findings regarding the effect of competence and compensation on employee performance at RM Saung Kabayan. follows:

The benefits of this research are as

a. Theoretical Benefits

The existence of this research is expected to be useful for the reader and be the material for the study of the effect of competence and compensation on employee performance at RM Saung Kabayan.

b. Practical Benefits

The author hopes that the preparation of this research can help business owners to consider employee performance in making decisions and policies.

\section{Literature Review}

\subsection{Tourism}

Etymologically, the word tourism comes from Sanskrit which consists of two syllables namely "pari" and "tourism". Pari means many times, circling, and complete. While tourism means travel or travel. Tourism itself is a plural meaning which is defined as things related to tourism, which in English is referred to as tourism. (Yoeti, 1996).

Tourism is always related to the facilities and infrastructure needed by tourists to support their tour. This facility has become one of the important aspects
L.L. UastIUHUHIIC I UuIIsIII

According to Soeroso in Turgarini (2018) gastronomy is science and art and even an appreciation which includes ethnic, nationality, race, group, religion, gender and culture to study food and beverage science for use in various situations and conditions in understanding gastronomy. itself does not only focus on its own culinary arts, but also on human behavior, including how to cook, serve, taste, feel and experience as well as searching, studying, researching and writing about food and everything related to human nutrition in every nation and country.

\subsection{Restaurant}

A restaurant is a commercially organized place or building that provides good service to all guests in the form of food and drinks. (Atmodjo,2005). Specialty Restaurant is a restaurant that serves special dishes from certain countries, so that the design, atmosphere of the place, as well as the service are aligned with the typical type of food and the origin of the food served.

\subsection{Human Resources}

Human resources include science and art that regulates the relationship and role of the workforce to be effective and efficient to help realize the goals of the company, employees and society (Hasibuan, 2007).

\subsection{Human Resources Managemet}

Mangkunegara (2013), human resource management, namely "a planning, organizing, coordinating, implementing and supervising the procurement, development, remuneration, integration, 


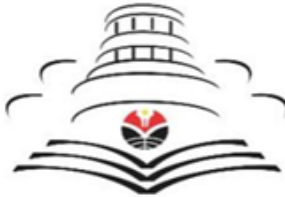

JURNAL UPI
THE JOURNAL GASTRONOMY TOURISM

Volume 6 Issue 2, December 2019, 95-110

Tersedia daring di:

https://ejournal.upi.edu/index.php/gastur

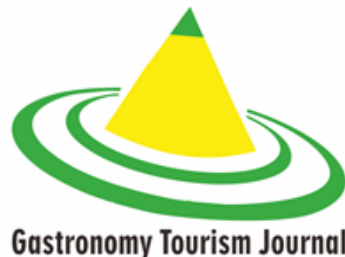

Gastronomy Tourism Journal procurement, development, compensation, integration, Maintenance, discipline, Separation. (Hasibuan, 2007)

\subsection{Competence}

Competence is an ability to carry out or do a job or task based on skills and knowledge and is supported by the work attitude demanded by the job. Thus, competence shows the skills or knowledge that are characterized by professionalism in a particular field as something that is most important, as superior in that field (Wibowo, 2007).

Competence provides benefits to various parties both for employees, organizations, and industry as a whole.

There are 5 (five) types of characteristics or competency components, namely:

a. Motive

Motives are things that are consistently thought or desired by people who cause actions. Motives encourage, direct and choose behavior toward certain actions or goals.

b. Trait

Traits are physical characteristics and consistent responses to situations and information. Trait is what makes a person have a behavioral attitude or how the person responds to something in a certain way.

\section{c. Self-concept}

The concept of self (self concept) is the attitude, values or self-image of a person. A person's confidence is a person's belief that they can be effective in almost every situation is part of the concept of self. d. Knowledge

Knowledge is information possessed by people in a specific field. Knowledge is a complex competency. Knowledge refers analytical and conceptual thinking.

\subsection{Compensation}

Compensation is something that is received by employees as a substitute for the contribution of their services to the company (Rivai, 2015). This compensation includes all income in the form of money, direct or indirect goods. Direct compensation (direct compensation) in the form of salary, wages and incentives, and indirect compensation (indirect compensation) in the form of insurance, benefits, leave and rewards (Hasibuan, 2007).

There are 4 indicators included in the compensation, namely:

a. Salary and wages

Wages are usually associated with hourly rates (the longer working hours, the greater the pay). While salaries generally apply to weekly, monthly, or annual pay rates.

b. Incentives

Incentives are additional compensation above or outside the salary or wages provided by the organization.

c. Allowances

Examples of benefits are health and life insurance, holidays covered by the company, pension plans, and others related to employment relations.

d. Adequate facilities

Examples of facilities such as pleasure or amenities such as company cars, club membership, special parking spaces, or access to company aircraft obtained by employees. Facilities that are represent substantial amounts and compensation especially for high-paid executives.

\subsection{Employee Performance}

Performance comes from 


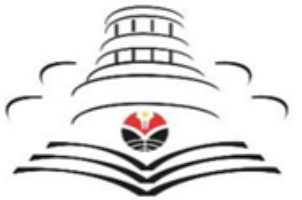

JURNAL UPI
THE JOURNAL GASTRONOMY TOURISM

Volume 6 Issue 2, December 2019, 95-110

Tersedia daring di:

https://ejournal.upi.edu/index.php/gastur

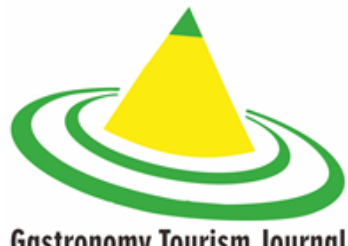

Gastronomy Tourism Journal the work process takes place. (W1bowo, 2007).

There are 5 aspects that determine a performance, namely:

a. Quality of work

Work quality (quality of work) which includes the work obtained, the conformity of work results with organizational goals, and the benefits of work results.

b. Timeliness

Timeliness (Promptness) which includes structuring activity plans or work plans, accuracy of work plans with work results, timeliness in completing tasks. Every work is endeavored according to plan so as not to interfere with other work.

c. Initiative

Initiative (initiative) is having self-awareness to do something in carrying out tasks and responsibilities. Initiatives can include giving ideas or ideas in organizing and actions taken to solve the problems encountered.

d. Ability

Ability (capability) includes capabilities, skills possessed, and the ability to use resources or potential.

e. Communication

Communication (communication) includes internal communication (into) the organization, external communication (outside) the organization, and building and maintaining cooperative relations in the implementation of tasks.

\subsection{Hypothesis}

Referring to the above research and to the research framework, the hypothesis of this study is that there is an influence between competence and compensation on the performance of employees of Saung Kabayan Restaurant Bandung. compensation, while the dependent variable (Y) is employee performance. This research was conducted at RM Saung Kabayan Bandung located at Jalan Dr. Djunjunan No. 107 Bandung (Terusan Pasteur), is the subject of this research are employees at RM Saung Kabayan Bandung. Then the study was conducted in less than 1 (one) year, namely in February 2019 August 2019.

This research uses descriptive and verification approaches. The method used was an explanatory survey with a sample of 56 people (saturated sample). Sugiyono (2015), "Saturated sample is a sampling technique when all members of the population are used as samples. This is often done when the number of pupulations is relatively small, less than 30 people, or researchers who want to make generalizations with very small errors. Another term for saturated samples is the census, where all members of the population are sampled. "

The type of data is information about everything related to the variable under study. Based on how to obtain it there are 2 (two) sources, namely:

a. Primary data

Primary data in this study are data obtained through the distribution of questionnaires to respondents (all employees of RM Saung Kabayan) where statements were first provided by researchers to support information data through the questionnaire.

b. Secondary data

Secondary data in this study came from the manager of RM Saung Kabayan, company documents, books and literature relevant to employee competency, compensation and performance.

Data collection in this study was 


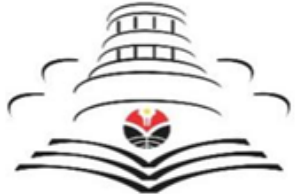

JURNAL UPI
THE JOURNAL GASTRONOMY TOURISM

Volume 6 Issue 2, December 2019, 95-110

Tersedia daring di:

https://ejournal.upi.edu/index.php/gastur

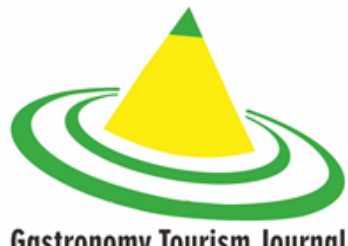

Gastronomy Tourism Journal interview is about issues related to competence, compensation and employee performance at RM Saung Kabayan.

d. Questionnaire

The questionnaire is a data collection technique that is done by distributing forms in the form of questions or written statements to respondents about the problems discussed in this study. (Sugiyono, 2015)

e. Observation

Observation or observation is a data collection method used to collect research data through the senses of researchers (Bungin, 2005). The form of observation in this study is direct observation, in which observations are made by researchers of the research object with the intention of getting true and accurate data.

\section{f. Literature study}

Literature study is a method of collecting data by studying books, papers, magazines and articles in order to obtain information related to theories.

\subsection{Validity and Reability Test}

The testing of the research instrument was carried out with the validity and reliability test. According to Sugiyono (2015) "the results of a valid study are if there is a similarity between the data collected and the data that actually occurs on the object under study". A valid instrument means that the measuring instrument used to get the data (measuring) is valid. Validity testing is done by using the SPSS for Windows version 25.0 program. in this study validity testing was conducted on 30 respondents.

Decision making based on the value of $r$ count $>r$ table of 0.361 , for $\mathrm{df}=30-2=$ $28, \alpha=5 \%$ then the item / statement is "reliability is a measurement that repeatedly produces the same or consistent results". That is, this reliability test tests the extent to which it is consistent with the instruments used in the study. So if the instrument were use again to examine the same object with the same technique, it will get the same results even though it is done at different times. This test is able to show the extent to which the instrument can be trusted or expected. The formula used to measure reliability in this study uses Alpha Cronbach. Cronbach's alpha is a mathematical formula used to test the level of reliability of a measure.

The following are the results of reliability testing conducted using the SPSS for Windows version 25.0 program. in this study reliability testing was conducted on 30 respondents. Recapitulation of the results of the reliability test is presented in the following table.

Table 3. Reability Test Result

\begin{tabular}{c|lcc}
\hline No & \multicolumn{1}{|c}{ Variable } & $\begin{array}{c}\mathrm{Ca} \\
\text { count }\end{array}$ & $\begin{array}{c}\mathrm{Ca} \\
\text { minimum }\end{array}$ \\
\hline 1 & Competency $\left(\mathrm{X}_{1}\right)$ & 0,938 & 0,700 \\
2 & Compensation $\left(\mathrm{X}_{2}\right)$ & 0,945 & 0,700 \\
3 & Employee & 0,937 & 0,700 \\
& performance $(\mathrm{Y})$ & & \\
\hline
\end{tabular}

Source: Data processing by author (2019)

Based on the results of the competence variable reliability, compensation and employee performance, all research instruments are declared reliable because they have a calculated $\mathrm{C} \alpha$ value greater than the minimum $\mathrm{C} \alpha$.

\subsection{Design Analysis and Testing Hypotheses}

Data analysis performed in this research is descriptive and verification analysis. Descriptive analysis aims to 


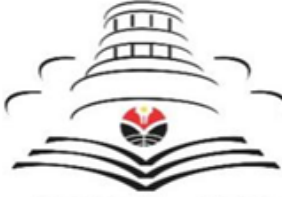

JURNAL UPI
THE JOURNAL GASTRONOMY TOURISM

Volume 6 Issue 2, December 2019, 95-110

Tersedia daring di:

https://ejournal.upi.edu/index.php/gastur

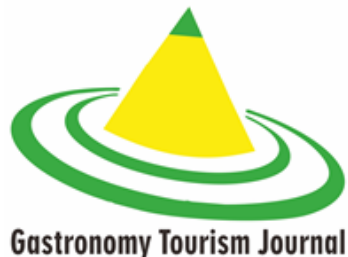

a. Descriptive analysis of competencies at RM Saung Kabayan

b. Descriptive analysis of compensation at RM Saung Kabayan

c. Descriptive analysis of employee performance at RM Saung Kabayan

While verification analysis is used to see the effect of competence (X1) and compensation (X2) on employee performance (Y) using multiple linear regression analysis techniques.

\section{Results}

\subsection{Overview of Research Objects}

Saung Kabayan is a Sundanese specialty restaurant in Bandung City, located on Dr. Djunjunan street, No. 107 Bandung or better known as Jalan Terusan Pasteur. Saung Kabayan has been established since 1988 which provides variations of Sundanese cuisine with a nuance of a distinctive place and accompanied by traditional Sundanese music to add to the atmosphere of the tempo.

Saung Kabayan Restaurant has various facilities for guests, namely: 2 (two) exclusive or VIP rooms with ac with a capacity of 15-20 people; middle room on the 2 nd floor in the form of a hall for birthdays, social gathering, meetings, presentations, etc. with a capacity of 100 people; public dining room on the 1st (one) floor with a capacity of 200 people.

\subsection{Characteristic of Respondents}

The study was conducted on 56 employees of RM. Saung Kabayan Bandung, the results of which have different characteristics. Characteristics based on sex consisted of 27 women $(48.21 \%)$ and 29 men (51.79\%). This shows that RM Saung Kabayan Bandung productive because employees are able to have a high enthusiasm in working

Then the respondent characteristics seen from the last education were dominated by high school / $\mathrm{K}$ graduates or $76.79 \%$. High school / $\mathrm{K}$ education is a standard for hiring employees at RM Saung Kabayan because high school / K graduates are considered to have sufficient skills in meeting job demands. Based on the length of work dominated by employees who have worked for $<2$ years. This is because the company recruited many new employees in early 2018 and 2019.

Characteristics of respondents based on status, showed that there were 24 employees $(42.86 \%)$ unmarried. Then as many as 28 employees (50\%) are married and as many as 4 employees $(7.14 \%)$ have ever been married. The explanation shows that the employees of RM Saung Kabayan Bandung are dominated by married employees.

Based on the work department, there are 3 admins, 4 cashiers, 17 large kitchens, 7 small kitchens, 4 drinking kitchens, 6 service equipment people, 5 security people, 2 vitring people, 2 public people and 6 waiters / ss . The number of employees in each department is determined based on company needs, it can be concluded that the majority of employees of RM Saung Kabayan are in the large kitchen department (as many as 17 people) or $30.36 \%$.

\subsection{Descriptive Testing Result}

Descriptive testing aims to present respondents' responses to the statements on the research questionnaire. Then the frequency of scores for each alternative answer is calculated so that the percentage and average score of respondents' answers 


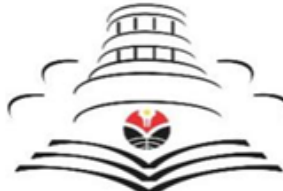

JURNAL UPI
THE JOURNAL GASTRONOMY TOURISM

Volume 6 Issue 2, December 2019, 95-110

Tersedia daring di:

https://ejournal.upi.edu/index.php/gastur

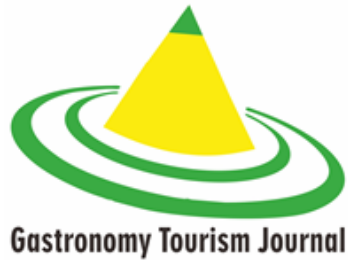

Gastronomy Tourism Journal indicator scores, it can be concluded that the highest score of the 12 statements obtained statements number 5 and 7 namely statements about "The level of confidence able to do the task" and "The level of ability to work together" with a score of 198. This shows that employees are able to work well together, then supported by high confidence in doing the task. While the smallest score is in statement number 12 which is the statement "The level of ability to determine the most effective work procedures" with a score of 173, this shows that most employees feel their ability to determine the most effective work procedures is the lowest score among the 11 other statements.

From the total dimension average score of 927 it is known that the dimension of self-concept has the highest value of the other dimensions, which is 192.7. The concept of self becomes an important part choose and interpret intormation and their biases in giving consideration (Wibowo, 2007).

The lowest value is found in the dimension of skills (skills) that is equal to 181. Skills need to be developed through a training process that is relevant to the job. However, based on field observations it is known that RM Saung Kabayan has never held training for its employees. The efforts to empower knowledge and high skills will result in higher employee capabilities as well. (Mangkunegara, 2013)

Then the recapitulation of respondents' responses regarding the competency variable got a score of 2,235 from an ideal score of 3,360 with a percentage of $66.52 \%$. These results indicate that the competency variable is included in the high enough category or lies at intervals of 1,748 to 2,286 .

Table 4. Reability Test Result

\begin{tabular}{|c|c|c|c|c|}
\hline No & Description & Score & Average & Ideal Score \\
\hline \multicolumn{5}{|c|}{ Motif ( Motive ) } \\
\hline 1 & Level of motivation for achievement & 185 & \multirow{2}{*}{183.5} & 280 \\
\hline 2 & $\begin{array}{l}\text { The level of motivation gets proper } \\
\text { compensation }\end{array}$ & 182 & & 280 \\
\hline \multicolumn{5}{|c|}{ Trait ( Trait) } \\
\hline 3 & Level of patience in doing work & 184 & \multirow[t]{2}{*}{187.5} & 280 \\
\hline 4 & $\begin{array}{l}\text { The level of friendliness towards fellow } \\
\text { employees, superiors or consumers. }\end{array}$ & 191 & & 280 \\
\hline \multicolumn{5}{|c|}{ Self-Concept ( Self-Concept ) } \\
\hline 5 & $\begin{array}{l}\text { The level of confidence is able to do the } \\
\text { task }\end{array}$ & 198 & \multirow[t]{3}{*}{192.7} & 280 \\
\hline 6 & $\begin{array}{l}\text { The level of adaptability in various } \\
\text { conditions }\end{array}$ & 182 & & 280 \\
\hline 7 & The level of ability to work together & 198 & & 280 \\
\hline \multicolumn{5}{|c|}{ Knowledge ( Knowledge ) } \\
\hline 8 & $\begin{array}{l}\text { The level of compatibility of knowledge } \\
\text { with the tasks entailed }\end{array}$ & 180 & \multirow[t]{3}{*}{184.3} & 280 \\
\hline 9 & $\begin{array}{l}\text { The level of mastery of tasks is based on the } \\
\text { knowledge they have }\end{array}$ & 181 & & 280 \\
\hline 10 & Level of desire to develop knowledge & 192 & & 280 \\
\hline
\end{tabular}




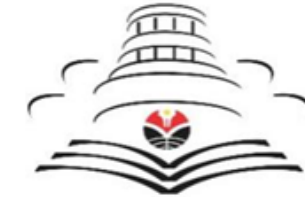

JURNAL UPI

\author{
THE JOURNAL GASTRONOMY TOURISM \\ Volume 6 Issue 2, December 2019, 95-110 \\ Tersedia daring di: \\ https://ejournal.upi.edu/index.php/gastur
}

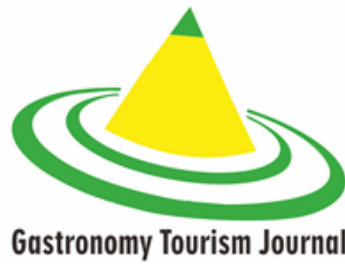

4.5. Description of respondents' responses to the compensation variable

Based on Table 5 the recapitulation results of the compensation variable indicator score can be concluded that the highest score of the 10 statements obtained statement number 9 is a statement regarding "The suitability of existing facilities based on employee needs" with a score of 168 . This shows that the facilities appropriate with employee needs. While the smallest score is in statements number 1 and 7, namely statements about "The level of conformity of salaries, wages and benefits" with a score of 130 , this shows that the salary, wages and benefits provided by the company is the lowest level of conformity that is considered among the 8 statements that are other.

Table 5. Results of recapitulation of compensation variables

\begin{tabular}{|c|c|c|c|c|}
\hline No & Description & Score & Average & Ideal Score \\
\hline \multicolumn{5}{|c|}{ Salary and Wages } \\
\hline 1 & $\begin{array}{l}\text { The level of suitability of salary and wages } \\
\text { according to the job }\end{array}$ & 130 & \multirow[t]{2}{*}{137.5} & 280 \\
\hline 2 & $\begin{array}{l}\text { The level of timeliness of the company in } \\
\text { providing salaries and wages }\end{array}$ & 145 & & 280 \\
\hline \multicolumn{5}{|c|}{ Incentive } \\
\hline 3 & The level of attractiveness of incentives & 139 & \multirow[t]{3}{*}{137.3} & 280 \\
\hline 4 & $\begin{array}{l}\text { The level of fairness of incentives is based } \\
\text { on performance results }\end{array}$ & 142 & & 280 \\
\hline 5 & Level of satisfaction with incentives & 131 & & 280 \\
\hline \multicolumn{5}{|c|}{ Alimony } \\
\hline 6 & The level of allowance provided & 138 & \multirow[t]{3}{*}{134} & 280 \\
\hline 7 & $\begin{array}{l}\text { Level of conformity of allowances and } \\
\text { expectations }\end{array}$ & 130 & & 280 \\
\hline 8 & Fairness of giving benefits & 134 & & 280 \\
\hline \multicolumn{5}{|c|}{ Adequate facilities } \\
\hline 9 & $\begin{array}{l}\text { The level of suitability of existing facilities } \\
\text { is based on employee needs }\end{array}$ & 168 & \multirow[t]{2}{*}{160.5} & 280 \\
\hline \multirow[t]{2}{*}{10} & $\begin{array}{l}\text { The level of completeness of the required } \\
\text { facilities }\end{array}$ & 153 & & 280 \\
\hline & Total & 1,410 & 569.3 & 2,800 \\
\hline
\end{tabular}

Source: Data processing by author (2019)

From the total dimension average score of 569.3 it can be seen that the dimensions of adequate facilities have the highest value of the other dimensions, which is equal to 160.5 . Adequate facilities can support employee performance. Suitability and completeness of facilities needed by employees is able to make employees work more effectively.

While the dimensions of benefits get the lowest value that is equal to 134 . These results indicate that the availability of benefits provided by the company is still considered poor and not in accordance with 


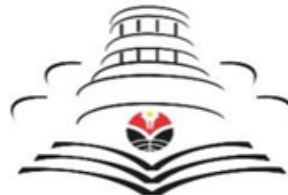

JURNAL UPI
THE JOURNAL GASTRONOMY TOURISM

Volume 6 Issue 2, December 2019, 95-110

Tersedia daring di:

https://ejournal.upi.edu/index.php/gastur

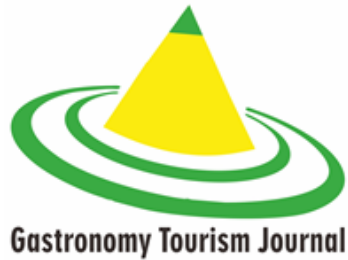

Gastronomy Tourism Journal level of compensation provided by the company is included in the low category because it is located at intervals of 1,008 to 1,456 .

4.6. Description of respondents' responses to employee performance variables

Based on Table 6, the recapitulation results of the indicator score of employee to communicate with coworkers. While the smallest score is in statement number 7 , the statement about "The suitability level of the skills possessed to support the work" with a score of 167, this shows that employees feel the skills possessed to support the work are at the lowest score among the 10 other statements.

Table 6. Recapitulation results of employee performance variables

\begin{tabular}{|c|c|c|c|c|}
\hline No & Description & Score & Average & Ideal Score \\
\hline \multicolumn{5}{|c|}{ Work quality ( Quality of Work ) } \\
\hline 1 & $\begin{array}{l}\text { The level of achievement of work results } \\
\text { according to company standards }\end{array}$ & 177 & \multirow[t]{2}{*}{174} & 280 \\
\hline 2 & $\begin{array}{l}\text { The level of work suitability based on } \\
\text { procedures }\end{array}$ & 171 & & 280 \\
\hline \multicolumn{5}{|c|}{ Timeliness (Promptnesss) } \\
\hline 3 & $\begin{array}{l}\text { The level of timeliness in carrying out tasks } \\
\text { according to plan }\end{array}$ & 190 & \multirow[t]{2}{*}{185} & 280 \\
\hline 4 & $\begin{array}{l}\text { The level of speed at which a task is } \\
\text { performed so as not to interfere with other } \\
\text { tasks }\end{array}$ & 180 & & 280 \\
\hline & Initiative & tive ) & \multirow{3}{*}{170.5} & \\
\hline 5 & $\begin{array}{l}\text { This level of initiative provides new ideas } \\
\text { in the organization }\end{array}$ & 168 & & 280 \\
\hline 6 & $\begin{array}{l}\text { The level of alertness is looking for } \\
\text { solutions to solve the problem }\end{array}$ & 173 & & 280 \\
\hline \multicolumn{5}{|c|}{ Capability ( Capability ) } \\
\hline 7 & $\begin{array}{l}\text { The suitability level of the skills possessed } \\
\text { supports the job }\end{array}$ & 167 & \multirow[t]{2}{*}{177.5} & 280 \\
\hline 8 & $\begin{array}{l}\text { The ability to maximize the potential } \\
\text { possessed }\end{array}$ & 188 & & 280 \\
\hline \multicolumn{5}{|c|}{ Communication ( Communication ) } \\
\hline 9 & Level of communication with coworkers & 194 & \multirow[t]{3}{*}{186.7} & 280 \\
\hline 10 & Level of communication with superiors & 193 & & 280 \\
\hline \multirow[t]{2}{*}{11} & $\begin{array}{l}\text { The level of communication with } \\
\text { consumers }\end{array}$ & 173 & & 280 \\
\hline & Total & 1974 & 893.7 & 3,080 \\
\hline
\end{tabular}

From the total dimension average score of 893.7 it can be seen that the communication dimension has the highest value from other dimensions, which is 186.7. Ability is any form of expertise, a skill that is inherent in a person to carry out an activity gained from learning and from experience (Soehardi, 2003). Therefore, the employees' abilities for having effect on performance, because the expertise and skills possessed by employees can help and facilitate employees in completing their tasks.

While the dimensions of the initiative (initiative) get the lowest value of 170.5. Initiative is the creativity that is owned by 


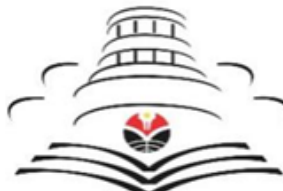

JURNAL UPI
THE JOURNAL GASTRONOMY TOURISM

Volume 6 Issue 2, December 2019, 95-110

Tersedia daring di:

https://ejournal.upi.edu/index.php/gastur

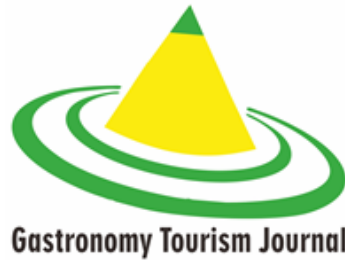

employee pertormance variables obtained a value of 1,974 from a total of 3080 ideal scots or a percentage score of $64.09 \%$. These results indicate the level of employee performance included in the category of high enough because it is located at an interval of 1,602 to 2,095 .

\subsection{Verification Test}

\subsubsection{Classical Assumption Test}

\subsubsection{Normality}

Test using the normal probability plot and the Kolmogorov-Smirnov test show that the data are considered to be normally distributed.and this result gives meaning that data processing is possible to be continued by using parametric statistics.

\subsubsection{Linerity}

Linearity test results show that the two variables have a linear relationship between competence and compensation with employee performance because the significance value based on the deviation from linearity is more than 0.05 .

\subsubsection{Multicollinearity}

Based on the multicollinearity test regression model.

\subsubsection{Heteroscedaticity}

Based on the results of the heteroscedasticity test showed that overall there were no symptoms of heteroscedasticity of each variable.

\subsubsection{Autocorrelation}

The autocorrelation test is useful to find out whether a linear regression model has a strong positive or negative relationship between the existing data on the research variable. In the procedure of detecting autokoleration problems, the Durbin-Waston quantity can be used. The autocorrelation test results showed that autocorrelation did not occur because the Durbin-Watson value was 1.805 , meaning that it was not less than 1 and not more than 3 .

\subsection{Multiple Regression Analysis}

Based on Table 7, it can be interpreted that the constant value $\mathrm{a}=7.792$, the coefficient $\mathrm{b} 1=0.567$ and $\mathrm{b} 2=0.192$.

Table 7. Results of Multiple Linear Regression Tests

\begin{tabular}{|c|c|c|c|c|c|}
\hline \multicolumn{6}{|c|}{ Coefficients $^{a}$} \\
\hline \multirow{2}{*}{\multicolumn{2}{|c|}{ Model }} & Unstan & Coefficients & Standardized & Sig. \\
\hline & & B & Std. Error & Beta & \\
\hline \multirow[t]{3}{*}{1} & (Constant) & 7,792 & 2,680 & & .005 \\
\hline & Competence & .567 & .065 & .732 & .000 \\
\hline & Compensation & .192 & .86 & .189 & .029 \\
\hline
\end{tabular}

Source: Data processing by author (2019)

Then the multiple linear regression equation between competence and compensation for employee performance is as follows:

$\mathrm{Y}=7,792+0,567(\mathrm{X} 1)+0,192(\mathrm{X} 2)$

Analysis Results: a. A constant value of 7,792 ; meaning that if the competency (X1) and compensation $(\mathrm{X} 2)$ the value is 0 , then the employee's performance $(\mathrm{Y})$ value is 7.792 .

b. Competency coefficient (X1) value is 


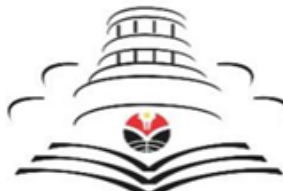

JURNAL UPI
THE JOURNAL GASTRONOMY TOURISM

Volume 6 Issue 2, December 2019, 95-110

Tersedia daring di:

https://ejournal.upi.edu/index.php/gastur

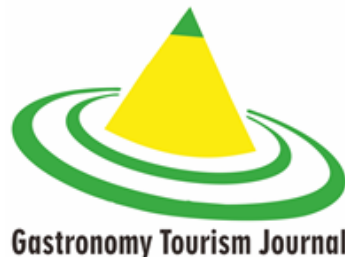

Gastronomy Tourism Journal coetticient (X') of U.1Y'; this means that if other independent variables have a fixed value, and compensation has increased $1 \%$, then employee coefficient of determination of the three variables can be seen from the following table:

Table 8. Correlation Analysis and Determination Coefficient

\begin{tabular}{ccccc}
\hline & \multicolumn{4}{c}{ Summary Model } \\
\hline Model & $\mathrm{R}$ & R Square & Adjusted R Square & $\begin{array}{c}\text { Std. Error of the } \\
\text { Estimate }\end{array}$ \\
1 & $.829^{\mathrm{a}}$ & .687 & .675 & 4,694 \\
\hline
\end{tabular}

Source: Data processing by author (2019)

Based on Table 8 it is known that the correlation value (r) of competence and compensation to employee performance at RM Saung Kabayan Bandung is 0.829, meaning that the strength of the relationship is included in the very strong category because it is in the range of $0.800-1,000$. This shows that there is a very strong level of simultaneous relationship between competence and compensation for employee performance. Furthermore, the coefficient of determination (R2) shows 0.675 . Then the result is:

$$
\begin{aligned}
& \mathrm{KP}=\mathrm{r} 2 \times 100 \% \\
& \text { Coefficient of Determination }= \\
& 0.675 \times 100 \%=67.5 \%
\end{aligned}
$$

These results indicate that each dimension of competence (X1) and compensation (X2) contributes $67.5 \%$ in improving employee performance (Y). While the remaining $32.5 \%$ were other factors not examined in this study.

\subsection{Partial Test (t-Test)}

Based on table 9 it can be seen the effect of each variable $X$ (competence and compensation) on the variable Y (employee performance).
Table. 9 Partial Test Results (t Test)

\begin{tabular}{llcl}
\hline \multicolumn{3}{c}{ Coefficients $^{\mathrm{a}}$} \\
\hline \multicolumn{2}{c}{ Model } & $\mathrm{t}$ & $\mathrm{Sig}$ \\
1 & (Constant) & 2,907 & .005 \\
& Competence & 8,673 & .000 \\
& Compensation & 2,241 & .029 \\
\hline
\end{tabular}

The value of the table can be seen in the table with the degree of validity (dk) $\mathrm{N}-2$ $=56-2=54$ and the significance level $\alpha=$ $5 \%$ that is equal to 1.674 . Then compare tcount with ttable, so we get the following results:

a. There is a significant influence between competence and employee performance because the significance value is 0.005 $<0.05$ and the tcount is 8.873> ttable 1.674 so $\mathrm{H0}$ is rejected and $\mathrm{Ha}$ is accepted. That is, partially there is a significant influence between competence and employee performance.

b. There is a significant effect between compensation and employee performance because the significance value is $0.029<0.05$ and the tcount is 2.241> ttable 1.674 so $\mathrm{H} 0$ is rejected and $\mathrm{Ha}$ is accepted. That is, partially there is a significant effect between compensation and employee performance. 


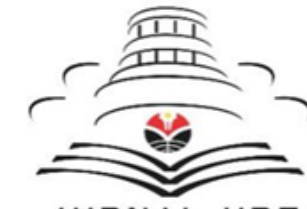

JURNAL UPI
THE JOURNAL GASTRONOMY TOURISM

Volume 6 Issue 2, December 2019, 95-110

Tersedia daring di:

https://ejournal.upi.edu/index.php/gastur

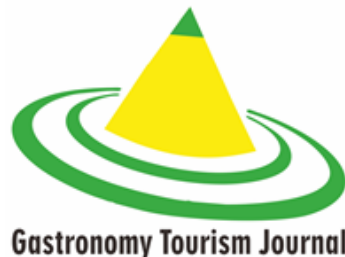

Gastronomy Tourism Journal
Rěsidual

Total

Source: Data processing by author (2019)

Based on table 10, the Fcount value is 58.234. As for the value of $F$ table with the degree of validity (dk) N-2 $=56-2=54$ and the significance level $\alpha=5 \%$ is equal to 3.17 . The $F$ value is the calculated $F$ value from the correlation between the competency variable $(\mathrm{X} 1)$ and compensation (X2) to the employee's performance (Y) as a whole with a probability level of Sig. 0,000. So thus the value of Fcount 58.234> Ftable 3.17, shows that $\mathrm{HO}$ is rejected and $\mathrm{Ha}$ is accepted, meaning that there is a significant simultaneous effect (together) of competence and compensation on the performance of employees of RM Saung Kabayan Bandung.

\subsection{Theoretical Findings}

Based on the results of research on competence and compensation for employee performance, the theoretical findings are as follows.

The researcher strengthens the research findings of Ataunur \& Ariyanto (2015) which states that "Competence has a positive and significant effect on the performance of the employees of PT. Adaro Energy Tbk ". Competence is a behavioral dimension that is behind competent performance that shows how people behave when they carry out their roles well (Armstrong, 2010). This shows that if the competencies of the employees are good, the performance shown will be good.

Researchers obtained the theory that compensation is a compensation for services or remuneration given by the company to the workers because the workers have contributed energy and thoughts for the progress of the company in order to achieve
2U13).

The researcher obtained a theory from Mangkunegara (2013) which argues that performance is the quality and quantity achieved by an employee in carrying out their duties in accordance with the responsibilities given to him. There are many factors that can affect employee performance. In the results of Devita \& Musadad's research (2017) revealed that the factors that influence employee performance at the Alpha Hotel Pekanbaru Hotel are the ability, skills and motivation. If concluded, the ability and skills included in the competency and motivation factors are closely related to the compensation factor.

The researcher strengthens the research findings of Tahir (2014) and Darso (2016) which states that competence and compensation simultaneously affect employee performance. Employee competencies will have a stronger influence on performance if accompanied by good compensation.

\subsection{Empirical Findings}

Based on the results of the study through the distribution of questionnaires to 56 respondents regarding the effect of competence and compensation on employee performance at RM Saung Kabayan Bandung, the following empirical findings are produced.

The findings of the research show that the competency variables consisting of motive, trait, self-concept, knowledge and skills score 2,235 or $66.52 \%$ of the ideal score. These results indicate the competence of employees of RM Saung Kabayan Bandung is included in the category of high enough or located at intervals of 1,748 2,286 in the continuum line. The highest 


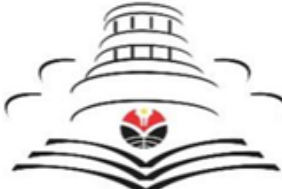

JURNAL UPI
THE JOURNAL GASTRONOMY TOURISM

Volume 6 Issue 2, December 2019, 95-110

Tersedia daring di:

https://ejournal.upi.edu/index.php/gastur

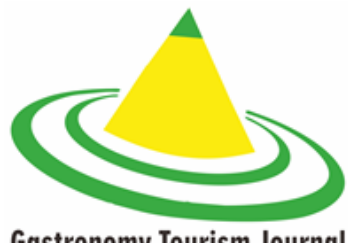

Gastronomy Tourism Journal partially there is a positive and signiticant effect between competence and employee performance.

Research findings of compensation variable consisting of salary and wages, incentives, allowances and adequate facilities show that the compensation variable obtained a score of 1,410 or $50.36 \%$ of the ideal score. The results show that the compensation of RM Saung Kabayan Bandung is in the low category or is located at intervals of 1,008 - 1,456. The highest score results are in the dimensions of adequate facilities, while the lowest scores are in the benefits dimension. Then the research findings show that compensation has a significance value of $0.029<0.05$ and tcount 2.242> t table 1.674, meaning that partially there is a positive and significant effect between compensation and employee performance.

The findings of the research finds that RM Saung Kabayan employee performance variables consisting of quality of work, promptness, initiative, ability and communication show that the performance variable gained a score of 1,974 or $64.09 \%$ of the ideal score. These results indicate that the performance of employees of RM Saung Kabayan Bandung is included in the quite high category or located at intervals of 1,602 - 2,095. The highest score is in the communication dimension, while the lowest is in the initiative dimension.

The research findings show that competence and compensation simultaneously have a positive and significant effect on employee performance because it has a value of Fcount 58.234> Ftable 3.17 with a probability level of Sig 0.000 . Then based on a correlation value of 0.829 and a coefficient of determination of $67.5 \%$ shows that competence and multiple linear regression analysis shows that $\mathrm{Y}=7.792+0.567 \mathrm{X} 1+0.192 \mathrm{X} 2$ means that if competence has increased $1 \%$ then employee performance has increased by 0.567 and if compensation has increased by $1 \%$ then employee performance has increased by 0.192 .

\section{Conclusion}

Based on a discussion of research on competence and compensation for employee performance conducted using multiple regression analysis, it can be concluded as follows:

Competence consists of dimensions of motive, trait, self-concept, knowledge and skills partially significant effect on employee performance. This shows that the competency of an employee plays an important role in improving performance. The highest score is the dimension of self-concept, while the lowest score is the dimension of skills.

Compensation consisting of salaries and wages, incentives, benefits and adequate facilities partially has a significant effect on employee performance. This shows that a good compensation system can improve employee performance. The highest score is the dimension of adequate facilities while the lowest score is the benefit dimension.

Competency and compensation simultaneously (together) have a significant influence on employee performance. This shows that the level of competency of employees and whether or not the management of compensation systems can affect employee performance improvement.

\section{References}

Atmodjo, MW (2005). Restaurant and all its problems. Yogyakarta: Andi 


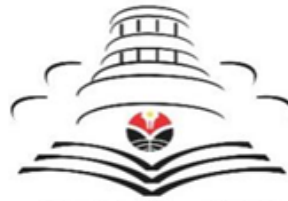

JURNAL UPI
THE JOURNAL GASTRONOMY TOURISM

Volume 6 Issue 2, December 2019, 95-110

Tersedia daring di:

https://ejournal.upi.edu/index.php/gastur

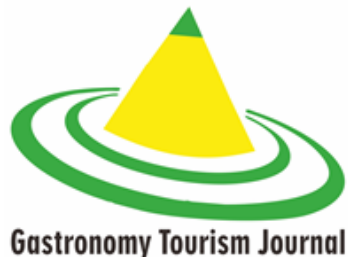

Gastronomy Tourism Journal
Bandung City Culture and I ourism Uttıce (2017). Indonesia.

Hadiyanto, D. (2013). The Effect of Competence, Compensation, and Job Satisfaction on Employee Performance at PT. Ciomas Adisatwa Balikpapan. Journal of Economics, University of Balikpapan, 1 (1), 1-14. https://doi.org/10.1021/acscatal.6b 02622

Hasibuan, MS. (2007). Human Resource Management. Jakarta: Earth Literacy.

Ismayanti. (2010). Pengatar Tourism. Jakarta: Grasindo.

Kusumah, RKY (2017). Effect of Competence and Work Attitudes on Employee Performance at Hashi Ramen Bar and Cimahi Resto, (6).

Mangkunegara, AAAP (2013). Corporate Human Resource Management. Bandung: Teen Rosdakarya.

Ningsih, C., \& Nuraeni, R. (2019). Developing a strategy of Chinatown as a halal gastronomic tourism destination in Bandung. ISOT 2018,259 .

Ridwan, \& Sunarto. (2012). Introduction to Education, Social, Economic, Communication and Business Statistics. Bandung: Alfabeta.

Rivai, V. (2015). Human Resource Management for Companies from Practice Theory. Jakarta: Rajawali Press.
Sundar, S. (2UI4). A study on the Intluence of Leadership Styles and Competency on Performance in the Manufacturing Industry. International Journal of Scientific Research, 3 (9).

Suswardji, E. (2012). The relationship of Competence and work discipline to the educational performance of Singapore University of Karawang, 10 .

Sutrisno, E. (2009). Human Resource Management. Jakarta: Kencana. Tahir, R. (2014). Competence and Compensation, and the Implications for Employee Performance. Journal of Business Administration, 11 (Number 4), 3222-3240.

Turgarini, D. (2016). Introduction Aceh traditional culinary as tourist attractions., 2.

Turgarini, D. (2018). Sundanese gastronomy as a tourist attraction in Bandung City. Gadjah Mada University, Yogyakarta.

Wibowo. (2007). Performance

Management . Jakarta: Rajawali Press.

Widyasari. (2004). Competency Based Education and Training (CBEIT) A Strategic Approach in Developing Competencies for Improving Organizational Performance.

Yoeti, OA (1996). Introduction to Tourism Science. Bandung: Space. 